\title{
The Role of Non-governmental Organizations in Empowering Women Political Representation in Nigeria
}

Chinazo Destiny Ewuru, Ku Hasnita Ku Samsu, Mohd. Mahadee Ismail

To Link this Article: http://dx.doi.org/10.6007/IJARBSS/v11-i12/11800 DOI:10.6007/IJARBSS/v11-i12/11800

Received: 12 October 2021, Revised: 18 November 2021, Accepted: 01 December 2021

Published Online: 26 December 2021

In-Text Citation: (Ewuru et al., 2021)

To Cite this Article: Ewuru, C. D., Samsu, K. H. K., \& Ismail, M. M. (2021). The Role of Non-governmental Organizations in Empowering Women Political Representation in Nigeria. International Journal of Academic Research in Business and Social Sciences, 11(12), 587-600.

\section{Copyright: (c) 2021 The Author(s)}

Published by Human Resource Management Academic Research Society (www.hrmars.com)

This article is published under the Creative Commons Attribution (CC BY 4.0) license. Anyone may reproduce, distribute, translate and create derivative works of this article (for both commercial and non0-commercial purposes), subject to full attribution to the original publication and authors. The full terms of this license may be seen at: http://creativecommons.org/licences/by/4.0/legalcode

$$
\text { Vol. 11, No. 12, 2021, Pg. } 587-600
$$

Full Terms \& Conditions of access and use can be found at http://hrmars.com/index.php/pages/detail/publication-ethics 


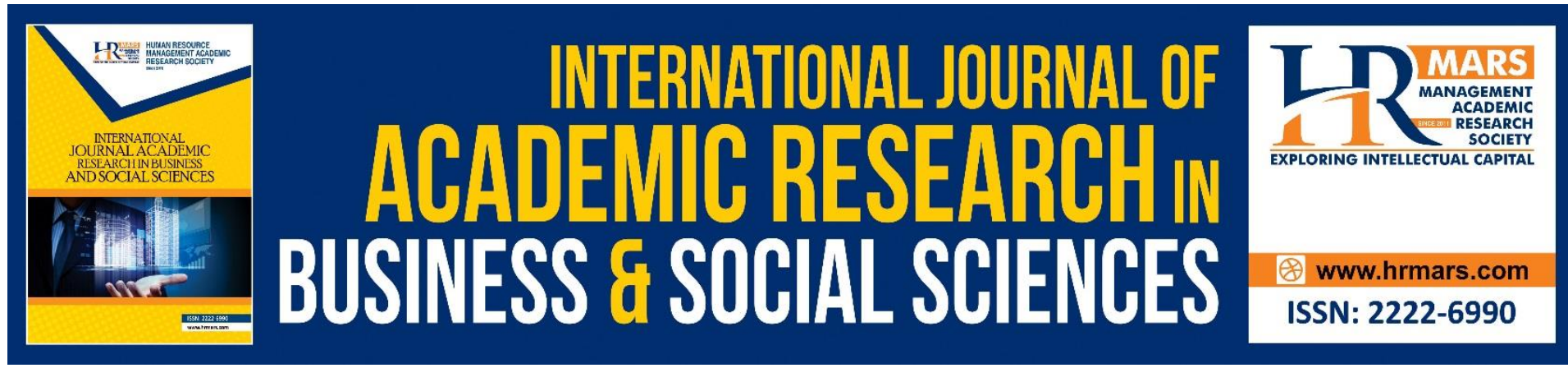

\title{
The Role of Non-governmental Organizations in Empowering Women Political Representation in Nigeria
}

\author{
Chinazo Destiny Ewuru, Ku Hasnita Ku Samsu, Mohd. \\ Mahadee Ismail
}

Department of Government and Civilization Studies, Universiti Putra Malaysia, 43400 Serdang, Selangor Darul Ehsan.

Email: hasnita@upm.edu.my

\begin{abstract}
The need for greater women political representation in government through collaborative efforts of non-governmental organizations in Nigeria is long overdue. Non-governmental organizations have a paramount role in ensuring greater political representation of women, especially in developing countries and in Nigeria in particular. Thus, this paper aims to assess the role of non-governmental organizations in empowering greater women political representation in Nigeria and the setback faced by these NGOs. Content analysis technique was employed in this study by using scholarly journals articles. The paper used about twenty scholarly journal articles retrieved from Google Scholar, Web of Science, Sage and other scholar search engine were sourced and used. The findings indicate that increasing women's political representation is achievable through the inclusion of critical stakeholders such as NGOs in the entire electioneering process. The findings also indicate the NGOs in their quest to empower women politically. They are often faced with setbacks such as the absence of political interest amongst the women and the lack of commitment of the critical stakeholders. Thus, the paper recommends the mass orientation and awareness creation of women in and around the country.
\end{abstract}

Keywords: Non-governmental Organization, Women, Political Representation, Democracy, Women's Right

Introduction

The significance of the political representation of women who form a majority of the Nigeria's citizen cannot be overemphasized. The need for the government to searchlight on women's political representation in Nigeria is long overdue, as this could energizes and collaborate as well as increasing the feeling representation in the women foe. A nation like Nigeria can't be wholly democratized without the dynamic representation of women, who comprise about half of the country's populace. When people are given equivalent benefit to participate in political dynamic, Nigeria generally acknowledges that women are still underrepresented in the country's political space. When women are the population isn't given equivalent chance 
to take an interest in political administration, the need to review the cause of the trend became necessary. Women political representation is now a global call as a predominate global treaties, covenants and declarations tend to encourage greater women involvement in affairs that concerns them, which has led to the emergence of some concepts and issues that incorporate women in development thrives (Arum \& Alaba, 2017), such as Women in Development (WID), Women and Development (WAD), Gender and Development (GAD) and Gender in Development (GID) among others (Arum \& Alaba, 2017).

The role of government in ensuring women political representation in Nigeria should be seen as an explicitly acquainted projects engaged in women issue through legislations, such as, National Policy on Women which was embraced and gone into law in addition to other things, dispense with every single unfair practice against women in governmental issues and private segments of the economy and governance (Fatile et al., 2013). National Gender Policy was presented on August 15, 2008, to destroy inconsistent sexual orientation power relations in the work environment issues, politics and economy. Investing in women can ensure greater women's political representation and guarantee an increase in women's political position in Nigeria and beyond (Olubunmi, 2010). Additionally, the Nigerian Women Trust Fund was initiated on March 24, 2011 in Abuja by the Ministry of Women and Social Development under Dr. Goodluck Jonathan's to ensure greater women's political representation in Nigeria. The Nigerian Women Trust Fund Program gave N100 million trust reserve to balance around 230 female applicants' battle cost independent of their ideological groups (Arum \& Alaba, 2017). It is important to note that the First Lady, Mrs. Jonathan presented a program that she called Women for Change Initiatives to help improve women's political representation. It also primarily target preparing support for women, thus encouraging a 30\% share ensured by the governmental policy regarding minorities in society strategy (Nelson, 2012). These projects have been depicted as tokenism since they didn't change to progress in the number of women challenging for elective positions (Arum \& Alaba, 2017).

Women's representation in decision-making in Nigeria has been shocking and disturbing since Nigeria's autonomy in 1960. In the last three decisions in the nation, the level of women that won elective positions was likewise extremely low. In 2007, in the House of Representatives, women were involved 27 seats out of 360 seats speaking to 7.5\%. In 2011, Women got 19 seats out of 360 seats speaking to 5.3\%. In 2015, women got 15 seats out of 360 seats, speaking to 4.1\% (Arum \& Alaba, 2017). In the Senate, in 2007, women got 9 out of 109 seats speaking to $6.4 \%$ (Odi, 2012). In 2011, seven female legislators were speaking to $6.4 \%$ (Odi, 2012). In 2015, there were 8 female representatives out of 109 individuals speaking to $7.3 \%$. The above examination shows that women support in administration through political race has been negligible. Ebegbulem (2012) contends that women are underestimated strategically and that it is just when a decent number of women hold open workplaces, they can start to address issues confronting them productively. Various reasons have been liable for women lackluster showing and investment in decisions. A portion of the reasons incorporates thuggery, economic imperatives, absence of training, male-controlled society, political savagery, social and social factors just as godfathers (Ebegbulem, 2012).

Therefore, this paper examines the role of NGOs in empowering women political representation in Nigeria. It also unravels the setback faced by these NGOs in their attempt 
to improve women's political representation in the country. In order to achieve the objectives of this study, content analysis technique will be employed by using scholarly journals articles.

\section{Understanding Political Representation}

Political representation is the propositional position occupied by certain people on behalf of a section of the country or nation. The idea of political representation is misleading because everybody recognizes what it is, yet few can concede to a specific definition. Actually, there is broad writing that offers a wide range of meanings of this slippery idea. Classic medicines of the idea of political portrayals inside this writing incorporate Pennock and Chapman (1968); Pitkin (1967); Schwartz (1988); Pitkin (1967) gives, maybe, one of the most direct definitions: to speak to is basically to "make present once more." On this definition, political representation is making residents' voices, conclusions, and points of view "present" in open arrangement making forms. Political portrayal happens when political entertainers talk, advocate, represent, and follow up for others' benefit in the political field. So, political representation is a sort of political assistant. This apparently clear definition, in any case, isn't satisfactory the way things are. For it leaves the idea of political representation underspecified. For sure, as we will see, the idea of political portrayal has various and contending measurements: our basic comprehension of the political portrayal contains extraordinary, and clashing, originations of how political agents ought to speak to this holds delegates to commonly inconsistent norms. In leaving these measurements underspecified, this definition neglects to catch this confusing character of the idea. Has become increasingly being a subject of debate for decades.

Pitkin offers one of the complete conversations of the idea of political portrayal, taking care of its opposing character in her The Concept of Representation. This exemplary conversation of portrayal is one of the most powerful and oft-referred works in the writing on political portrayal. (For a conversation of her impact, see (Dovi, 2016). Receiving a Wittgensteinian way to deal with language, Pitkin keeps up that to comprehend the idea of political portrayal, one must consider the various manners by which the term is utilized. Every one of these multiple employments of the term gives an alternate perspective on the idea. Pitkin looks at the idea of portrayal as "a somewhat confused, tangled, three-dimensional structure in a dull fenced-in area." Political scholars give "streak bulb photos of the structure taken from various points" [1967, 10]. All the more explicitly, political scholars have given four primary perspectives on the idea of portrayal. Lamentably, Pitkin never clarifies how these various perspectives on political portrayal fit together. Now and again, she suggests that the idea of portrayal is bound together. On different occasions, she stresses the contentions between these various perspectives, for example, how spellbinding portrayal is against responsibility. Drawing on her glimmer bulb similitude, Pitkin contends that one must know the setting where the idea of portrayal is put in a request to decide its importance. For Pitkin, the contemporary utilization of the expression "portrayal" can significantly change its significance.

For Pitkin, contradictions about representation can be in part accommodated by explaining which perspective on representation is being conjured. Pitkin distinguishes four distinct perspectives on representation: formalistic portrayal, spellbinding portrayal, emblematic portrayal, and considerable portrayal. (For a short depiction of every one of these perspectives, see outline beneath). Each view gives an alternate way to deal with looking at 
portrayal. The various perspectives on representation can likewise give various gauges to surveying agents. So contradictions about what agents should do are bothered by how individuals receive an inappropriate perspective on portrayal or twist representation guidelines. Pitkin has from multiple points of view set the conditions of contemporary conversations about portrayal by giving this schematic outline of the idea of political portrayal. Political representation as discussed in this section accurately captures the tenet of this article. This paper views political representation as to the ability of the women fox to be aptly and increasingly represented in the political system of the country Nigeria. Political representation is not just the presence of women fox in political offices but the adequate, greater, and increased representation in the political system they found themselves in Nigeria.

\section{Women Representation in Developing Countries}

Women's political under-representation is a recurrent issue. The poor representation of women in developing countries is alarming. And ironically, half of the world's voting population are women. Unfortunately, the average per cent of women in the national parliament and executive positions is not even a fifth of the entire members of countries parliament (18.7\%), average for women in national parliament is not different, even in both single or lower house (Abubakar \& Ahmad, 2014). The representation of women in politics where men and women are equally represented, although rare is called a gender-balanced representation (Abubakar \& Ahmad, 2014). An examination of the political representation of countries and their legislative bodies shows that women are greatly under-presented. According to Phillips (2000), the under-representation of women and certain groups includes ethnic, racial, class, or religious groups opined that the population should not be divided into different groups, but the under-represented in politics and other spheres of society be the priority. However, it is difficult to neglect the under-representation of some groups in society whose present cannot be neglected despite the insufficient attention to particular questions.

Several arguments for a gender-balanced representation and in particular women representation have been brought up including one of the ground pillars of democracy; and women's equal right to participate in politics, vote, and stand as a candidate and participate in decision-making processes (Dahl, 2007:345). The debate for women political representation in a democracy is brought up often because of the important and evergrowing politics of presence. This implies the women should be able to participate and be represented in politics to ensure that their opinions are represented in the decision-making process. The Convention on the Elimination of all Forms of All forms of Discrimination against Women (CEDAW) adopted by the UN in 1979 has also been helpful. CEDAW requires the 186 countries who ratified it to eliminate those hindrances for citizens, regardless of gender, to have equal possibilities and equal rights. One key article ensures women's equal possibility to participate in political and public life (United Nations Treaty Collection, Convention on the Elimination of All Forms of Discrimination against Women, Status as of 14 September 2010). Existing literature provided a guide to a better understanding of NGOs' role in ensuring the increase in women political representation.

\section{Methodology}

The objective of this paper was basically to assess the role of the non-governmental organization in empowering greater women's political representation in Nigeria and the 
setback faced by these NGOs, and to achieve the set objective, the paper used content analysis technique. Data for the paper was sourced from scholarly journals articles. About twenty scholarly journal articles gotten from Google Scholar, Web of Science, Sage, and other academic search engine was sourced and used. The content analysis tool used for this research was systematically positioned to determine the presence of certain words and themes within some given qualitative data and with a focus on the secondary data sourced. Using the content analysis, researchers of this article quantify and analyze the presence of phenomena such as NGOs' role in greater women's political representation in Nigerian politics. The content analysis process also allows the researchers to draw the meanings and relationships between the NGOs and women's political representation through the themes that emerged in the paper. The article context was broken down into manageable code categories in analyzing the text from the secondary data sources. The researchers further evaluated the context within which women's political representation was used in the articles selected for the paper to arrive at findings such as funding and advocacy as a tool used by the NGOs towards greater women's political representation in Nigeria. The researchers further made inferences about the messages within the texts, so that the readers can better understand the text.

\section{The Role of NGOs in Empowering Women Political Representation in Nigeria}

The role of non-governmental organizations in women political representation can be overemphasized. The NGOs in some cases have design principles and policies, taken actions that aim at improving women political representation and ending gender inequality in the Nigerian political system. The NGOs in Nigeria and other international organizations often advance and undertake and influence government policies, international organizations, and non-governmental organizations in an attempt to ensure greater women political representation in Nigeria (Abubakar \& Ahmad, 2014; Kusimo \& Kusimo, 2021). To Abubakar \& Ahmad (2014), it is important to note that under the President Goodluck Ebele Jonathan's administration the fulfillment of his promise to ensure at least $30 \%$ women's representation in his government through affirmative action received commendation globally because of the efforts put in place by the NGOs in the country and beyond, although more has to be done, particularly in women contesting and winning elective positions in the various political parties.

Through the pro-active drive of the NGOs the President of the Federal Republic of Nigeria has recently shown his desire to respect gender targets by appointing 13 women among his 42 member cabinet which is uncommon in the recent history of the country. This has demonstrated a high level of commitment put in place by the NGOs and their drive for the National Gender Policy (NGP). According to Olufemi and David (2011), the various NGOs advocating for greater women's political representation have helped awaken a sense of consensuses. NGOs and other prominent international organizations were among the key actors that agitated and advocated for the improvement of women political representation which impact is being felt today in the country. An international organization such as the United Nations Convention for Elimination of all Forms of Discriminations against Women (CEDAW), played a prominent role in improving women political representation in Nigeria and worldwide; others such as CEDAW (Abubakar \& Ahmad, 2014; Duintjer \& Thompson, 2018; Ahmad et al., 2019; Brass, et al., 2018). Scholars have advocated for women's representation 
and equality both for sexes in the political process and political system in general, as well as the integration of parts of the modern political system.

Hence, it can be said that the recommendation that all available majors should be taken to improve women political representation, the Beijing conference in 1995 which centered on discriminatory attitude, practices and unequal power relation are product of NGOs and other international organizations struggle for greater political representation. According to Abubakar \& Ahmad (2014) the NGOs have demonstrated how cultural beliefs and institutional bottlenecks affects women's political representation, as well as stressed the role of affirmative action in tackling women's underrepresentation and marginalization in politics.

The NGOs in the quest to increase women's political representation in Nigeria often adopt some strategies which shall be discussed in the subsequent sections. Country Women Association of Nigeria (COWAN), with three schemes namely COWAN African Traditional Responsive Banking (ATRB), COWAN Grass Root Health Insurance Scheme and Women Political Participation and Development Fund (WOPOPADEF) through these programs, has been able to sharpen women ideas to cast a ballot for themselves and the rightful candidates (Arum \& Alaba, 2017). According to Arum \& Alaba (2017), these non-governmental organizations even support female government officials through the program which request women to work together. Thus, if any woman yearning for any political office involves conversing with working gatherings and getting the working class to help her, the woman is now certain about more votes from COWAN. As indicated by COWAN, they additionally support female legislators. They give them cash to make banners and for coordination. They likewise help them to peddle for votes. They reviewed of a woman that disclosed to them that she is keen on challenging for chairmanship position of a neighborhood government. COWAN as a non-governmental organization helps women to make political decisions. They appropriated advances to those in government on behalf of the woman. They also reviewed how a male hopeful brought sacks of rice, salt, and tomatoes to share with women to get their votes. As they indicated, the woman assembled everything and gave the man back (Arum \& Alaba, 2017). As indicated by them, WOPOPADEF is one of the different results of COWAN that explicitly target woman strengthening. The model is intended to sharpen the womenfolk and give a stage to connect the wide hole of inconsistent portrayal among ladies and their men partners on the political scene. COWAN activation procedure rotates around a home developed political mindfulness model labelled "The One hundred-woman working Group" in trust. In every neighbourhood government geo-political set-up, there are ten discretionary wards. COWAN guarantees that apart from each ward is associated with coplanning ten different individuals. The One Hundred-Women Working Group so recognized turns into the arrow points for connecting with others in tens (Arum \& Alaba, 2017).

The strategy used by these Non-governmental organizations is advocacy. Like the National Council of Women Societies (NCWS) often used her umbrella body to advocate for greater women's political representation in Nigeria. NCWS has about 300 women groups under them who most times are found under the work with Ministry of Women Affairs of the country. NCWS basically advocate for women political representation through programmes. They organize seminars to encourage women to take active part in politics (Arum \& Alaba, 2017). Again, lobbying remains an all-important strategy used by these women organization. They often lobby the national assembly to make laws in the interest of the women, for example 
lobbying for the office of the First Lady to be recognized constitutionally through which women representation will be felt (Arum \& Alaba, 2017; Onimisi, 2014).

\section{Understanding the Setbacks in Women Political Representation in Nigeria}

Table 1 and 2 give the adversely low figures of elections respectively women representation in politics between 2003 and 2007 in the House of Representative and in the Senate. Both illustrate the level of women political representation in the Nigerian National Assembly. The tables show that women's political representation level has not been encouraging as it has never gone beyond 35 per cent, which is the United Nations recommendation.

In numerous African nations, for example, Nigeria, disagreeable accepted practices, political avoidance and financial imbalance direct the nearness and voice of women in politics in the country. As per the 2006 Nigerian populace enumeration figure, women established $49 \%$ of the complete populace, yet there has been a gross sexual orientation hole among people, particularly in political portrayal, financial administration and initiative (Okafor \& Akokuwebe, 2015). Political imbalance is much in African nations in Nigeria particularly, albeit some advancement has been made. As men have authority over resources and have moderately better instruction, they have a predominant situation as far as a political force. For example, men councillors may not be exceptionally instructed; however, such positions are not given to women with a similar low instructive level. The absence of mindfulness prompts circumstances where they become reliant on male political positions or ideological groups. Men's cooperation in the initiative will concentrate more on issues of men's enthusiasm than on women's interests. Now and again, women are chosen into an initiative situation in the arm of government without really taking an interest in real administration in most cases in Nigeria (Okafor \& Akokuwebe, 2015; Onimisi, 2018).

In Nigeria, a ton of women need compelling force or impact, particularly in government structure. A significant number of them don't have the fundamental aptitudes to introduce thoughts adequately. The absence of attention to political interest implies lacking the commitment to open issues and women strengthening. Whenever women are given the chance of investment in authority, they will perceive these issues and address them to oblige full interest of women in the initiative at all degrees of the arms of government. One of the significant reasons women have not gotten sufficient advantages from long stretches of arranging and advancement is their insufficient portrayal, non-cooperation and nonassociation in planning and executing plans for their monetary turn of events 
Table 1: Comparison of women elected by state, 2003 \& 2007 Nigeria National Assely, House of Representatives

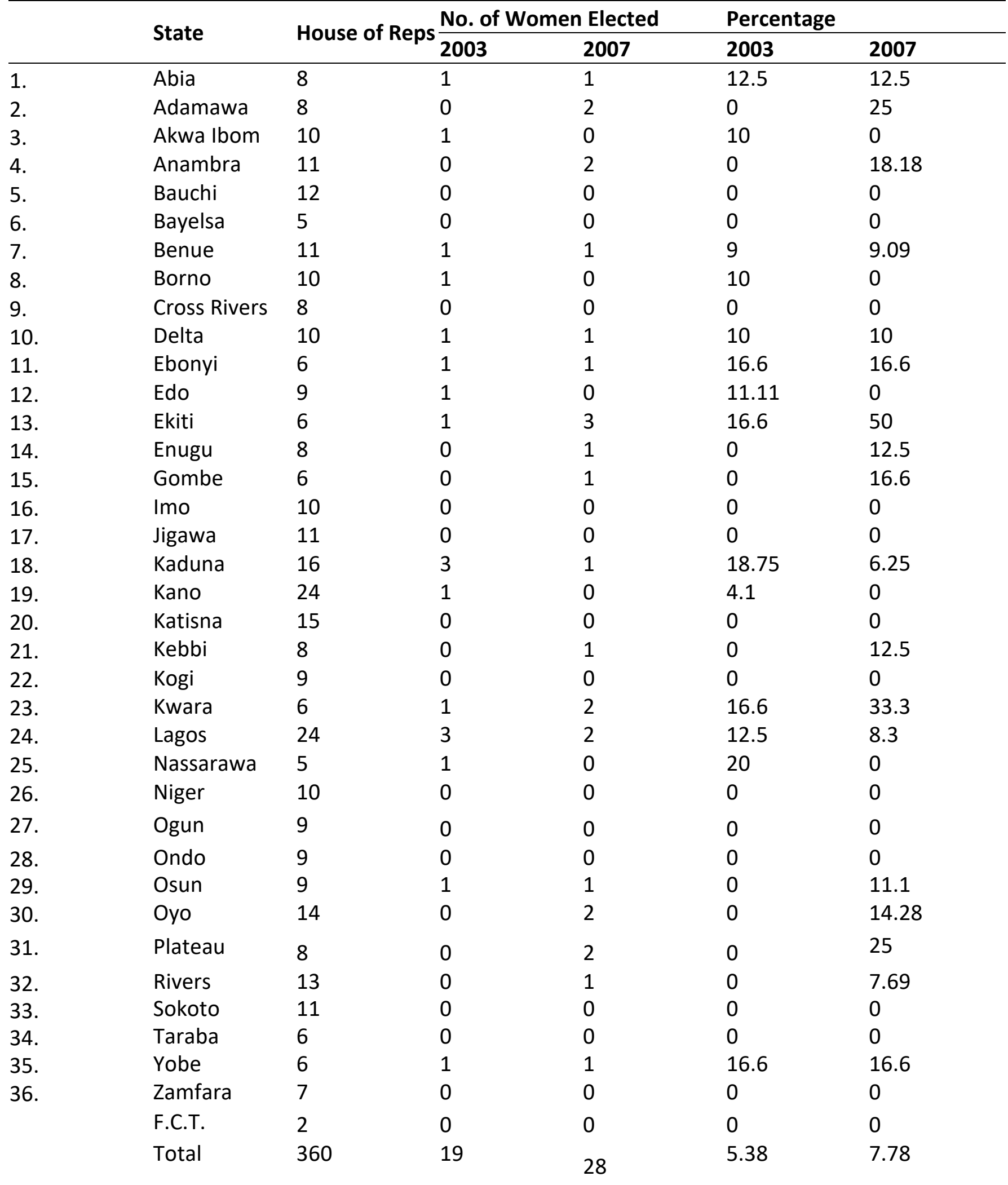

Source: Etubom Bassey - Ekpo and Nkoyo Toyo (eds.), Nigerian Women \& Political Entrism: Power, Intrigues, and Obstacles around the 2003 Election; NDI, GADA and INEC Lists of women elected in 2007. [32] in Odebiyi \& Iwuagwu (2018). 
Table 2: Comparison of Nigeria women elected by the state $2003 \& 2007$ Senate Elections

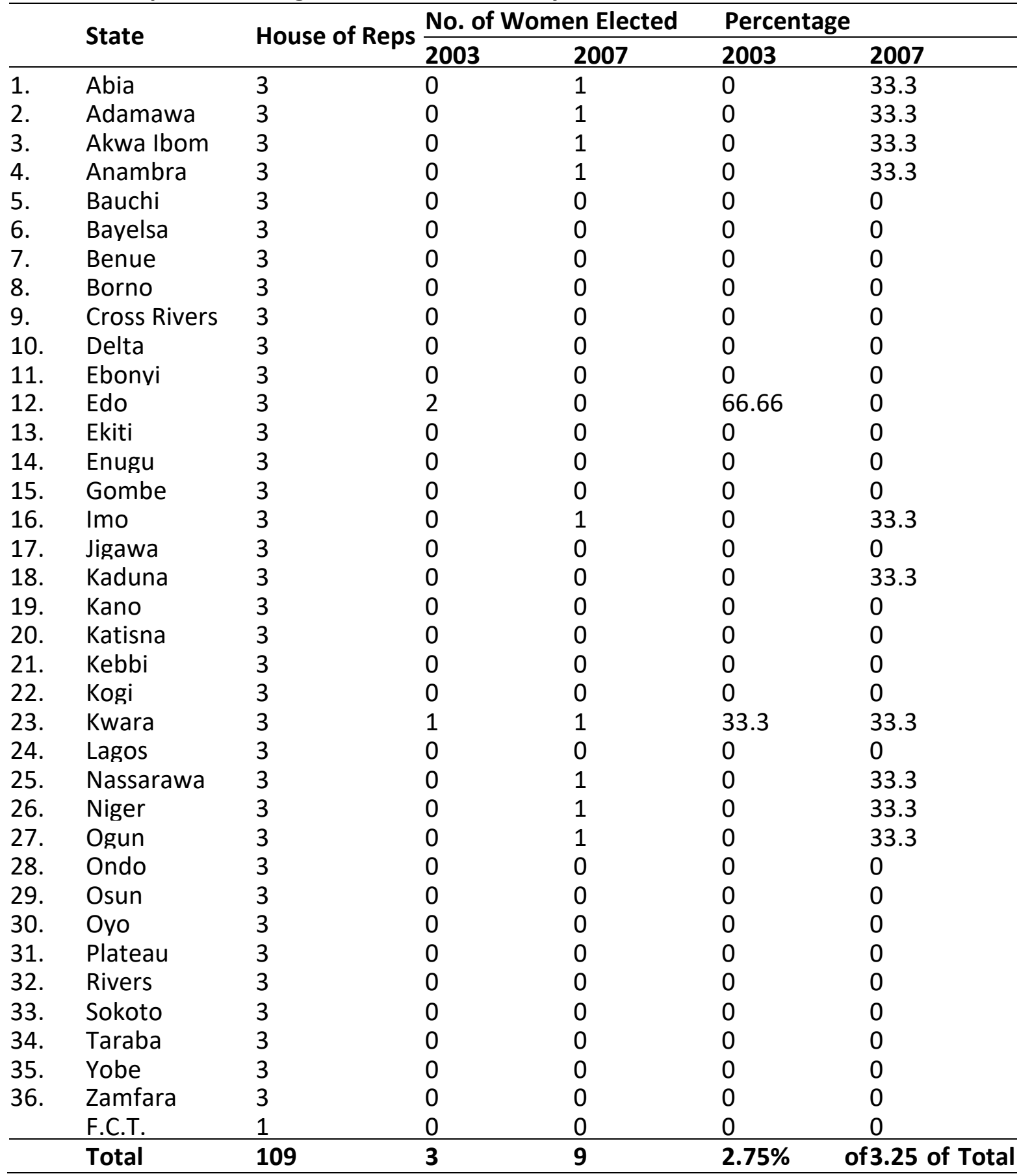

Source: Extracted from INEC List of Senators Elect, Nigerian National Assembly, 2007 [32].

and social equity through decentralized organizations. Most ideological groups don't keep up information on their ladies enrollment and not many ladies are allowed tickets for decisions (Shamim and Kumari, 2002). Since governmental issues is generally a male area and all money related, monetary, business and political dealings led outside the house are by guys, Nigerian women have exceptionally restricted access to dynamic procedure, and they have a serious absence of access to and power over budgetary assets (Okafor \& Akokuwebe, 2015). This successfully diminishes women opportunity to challenging races. The elements and issues of women minimization and low support in political administration and dynamics have drawn in a ton of consideration from researchers. In spite of the fact that women and men have diverse 
organic and physiological make-up, women may impart normal highlights to men as far as instructive capabilities, financial status and occupation, among others. However, they are minimized in practically all circles of open life. In rising majority rule governments, a few factors keep ladies from taking an interest completely in political authority and administration in all types of government and political positions/workplaces.

Offensive socio-social practices, for example, widowhood rehearses, female genital mutilation (FGM), prohibitive strict practices (as saw in the Northern geo-political zone), and purdah framework (saw in the northern piece of the nation). A considerable lot of these sociosocial practices obstruct ladies' strengthening and sexual orientation fairness, putting a more substantial weight on ladies. The covering various prohibitions and hardships looked at by women in social and customary convictions frequently deny them access to data, instruction and riches making resources, for example, land, capital (counting credit offices), work, and enterprising aptitudes (Aina, 2012). These limitations caused by socio-social practices can be accused of the helpless investment of ladies in legislative issues and authoritative dynamic procedures.

\section{Conclusion}

Despite everything, there is no uncertainty that women remain exceptionally underestimated in all political spheres of Nigeria's representation. This is all the more glaring now when the extent of men to women political representation in the legislative arms is obviously low and other dynamic positions are analyzed. Women in Nigeria are not incorporated into the political representation of the country because of the socio-social practices, absence of accountability and women lack of support, lack of strict separation, absence of political financing, lack of education and deficient training, minimization in ideological group chain of command, man controlled society settings, early relationships, and cliché requirements among others, have been recognized as repressing ladies' low interest in administration and legislative issues. There ought to be the incorporation of sexual orientation delicate arrangements in the constitutions and manifestoes of political gatherings. This will encourage women representation.

There is likewise a dire requirement for the foundation of a Women's Political Institute where political gatherings and every women competitor and contestant will be outfitted with significant abilities that support the situations in government, they look for a run for. This will assist them with improving their degree of training to empower them to adapt to the difficulties they may experience as an aftereffect of political necessity. Women should be dynamic in battling against defilement and pay off in decisions. They ought to be at the front line in calling for discretionary changes to confine cash utilization in decisions. So as to have women partake in politics and administration and legislative issues, sexual orientation fairness activities ought to be executed at all degrees of administration. The administration needs to progress in the direction of changing the political structures which produce sexual orientation imbalances. Women gender disparity ought to be tended to correspond to women hardship, financial and political elements. Accomplishing the objective of equivalent investment of women and men in dynamic positions will give a parity that mirrors the organization of society, premiums and the general great all things considered. At last, for there to be a more noteworthy interest of women in all circles of Nigerian culture, 
government and different partners ought to take part in projects and approaches that would engage women strategically, socially and monetarily.

Women in authority positions, particularly in creating nations, have the obligation and the possibility to impact their public through administration, especially when they are empowered. Empowered women are engaged yearn for, accomplish and perform well in administration positions while doing their jobs on the home front. Women should be empowered when they are taught, uncovered and financially liberated. Throughout the ages and in all nations, women in initiative positions have affected decidedly on the public. The historical backdrop of humankind is packed with such women. The only remaining century saw the development of extraordinary women pioneers in different circles of human undertakings, remarkably were achievers in positions of authority in Nigeria. Do the trick to state that the current Nigerian government has given more women chances to serve as leaders in different limits than some other past organization. Some women pioneered the path in their different callings and kept on exceeding expectations in their undertakings in zones, such as medication, drug store, policy implementation, and different callings. Nigeria is the most crowded dark country on the planet and has, from recorded occasions, created women pioneers and achievers. Just administration in Nigeria goes back to her autonomy on October 1, 1960. Be that as it may, there have been intervals of common war and irregular military invasions into administration. These occasions put Nigeria into the association of rising majority rules systems when truth be told; she ought to be a moderately aged votebased system. The majority rules system should accord equivalent chances, rights and benefits to all people, regardless of sex, race, religion, etc. This, subsequently, assumes there is a level and reasonable playing ground for development into open initiative positions.

Next are suggestions that will improve women's support in administration in Nigeria: favorable government approaches to kill or decrease the neediness rate among women are required. Foundation of a working Ministry of Women Affairs will be generally helpful to address the issues confronting women. Preparation and re-training of Nigerian men towards women strengthening there ought to be compulsory and upheld training for the young women at all instruction degrees. Concurring women full rights to cast a ballot and be decided in favor of. Approaches that forestall brutality, dread and terrorizing, particularly during decisions ought to be actualized. Arrangement of great conditions that will advance women's work, including proficient and specialized preparation, ought to be made. There ought to be assured that women should accept initiative situations in the general population and private parts. There ought to be law-based and impartial interest being developed procedure through office holding to give power over the allotment of assets. Procurement of the correct authority abilities, particularly subjective training. There ought to be the destruction of the absence of education through mass grown-up proficiency and tutoring for young women.

\section{References}

Abubakar, M., \& Ahmad, Z. B. (2014). Women and political participation: Toward attainment of $35 \%$ affirmative action and obstacles to the women participation in Nigerian politics and decision making process. Journal of Research in Humanities and Social Sciences, 2(9), 65-71.

Ahmad, G. I., Ahmad, M. K., \& Lynn-Sze, J. C. (2019). Exploring the Muslim-focused cultural sensitivity in polio vaccination communication campaign in Northern Nigeria. 
Aina, O. I. (2012). Two halves make a whole: Gender at the crossroads of the Nigerian development agenda. An Inaugural Lecture Delivered at the Oduduwa Hall, Obafemi Awolowo University, Ile-Ife, Nigeria on Tuesday 25th, September, 2012. Pp. 70-76.

Arum, I., \& Agagu, A. (2017). Non-Governmental Organizations and Women Political Participation in Ondo State, Nigeria. International Journal of Case Studies, 6(4).

Blomgren, E. (2010). Women and Political Participation: A Minor Field Study on Hindrances for Women's Political Participation in Georgia.

Brass, J. N., Longhofer, W., Robinson, R. S., \& Schnable, A. (2018). NGOs and international development: A review of thirty-five years of scholarship. World Development, 112, 136-149.

Bryson, V., \& Campling, J. (2003). Patriarchy and the Family. Feminist Political Theory-An introduction. Great Britain: Palgrave Macmillan.

Dahlerup, D. (2013). Women, quotas and politics. Routledge.

Tebbens, D. R. J., \& Thompson, K. M. (2018). Using integrated modeling to support the global eradication of vaccine-preventable diseases. System Dynamics Review, 34(1-2), 78-120.

Ebegbulem, J. C. (2011). Credible elections and democratic consolidation in Nigeria: the moral imperatives. Journal of Emerging Trends in Educational Research and Policy Studies, 2(4), 246-250.

Jacob, F. O., Ighodalo, A., Justine, C., \& Okpo, O. C. (2012). Feminism and political participation in Nigeria: An empirical analysis. International Journal of Asian Social Science, 7(1), 1077-1092.

Kusimo, N. O., \& Kusimo, M. O. (2021). Now that Nigeria is polio-free: The effects that social mobilisation programme on polio immunisation program had on the hard to reach parents of children eligible for immunisation programmes in Nigeria. International NGO Journal, 16(1), 1-8.

Nelson, E. (2012). Women Political Participation in Nigeria. International Journal of Advanced Legal Studies and Governance, 3(1).

Odebiyi, O. A., \& Iwuagwu, O. (2018). Challenges Facing Women in Politics; A Case Study of Lagos State. Journal of Social Sciences and Humanities, 1(2), 110-120.

Odi, M. (2012). Women's Political and Civic Participation in Nigeria, Opportunities and Challenges to the Full Realization of Democracy, presented during the 5th convening of the International Women's Democracy Network during the World Movement for Democracy's Seventh Assembly in Lima, Peru.

Olufemi, J., \& David, K. (2011). Gender issues in human resource management in Nigerian public service. African Journal of Political Science and International Relations, 5(3), $112-$ 119.

Okafor, E. E., \& Akokuwebe, M. E. (2015). Women and leadership in Nigeria: Challenges and prospects. Developing Country Studies, 5(4).

Onimisi, T. (2015). The Prognoses of the 2011 Electoral Violence in Nigeria and the Lessons for the Future. Mediterranean Journal of Social Sciences, 6(1 S1), 242-242.

Onimisi, T. (2018). Trends of human rights abuse in Nigeria: 1996-2013. International Journal of Advanced Studies in Social and Innovation, 2(2), 70-79.

Shamim, I., \& Nasreen, M. (2002). Gender and local governance: A new discourse in development. Journal of Social Studies-Dhaka-, 50-87.

Sokefun, O. A. (2010). Women development and national policy on women in Nigeria. Multidiciplinary Journal of Research Development, 15(1), 1-11. 
Sumbadze, N. (2008). Gender and society: Georgia. Tbilisi: United Nations Development Programme.

Schwartz, N. L., \& Schwartz, N. L. (1988). The blue guitar: Political representation and community. University of Chicago Press.

Pennock, J. R., \& John, W. (1968). Chapman, eds. Representation. New York: Atherton Press.

Phillips, A. (2000). Närvarons politik - den politiska representationen av kön, etnicitet och ras. Studentlitteratur. Lund. Original "The Politics of Presence" (1995). US: Oxford University Press.

Pitkin \& Hanna. (1967). The Concept of Representation. Los Angeles: University of Press. 